EUROPEAN UNIVERSITY INSTITUTE, FLORENCE

DEPARTMENT OF POLITICAL AND SOCIAL SCIENCES

EUI WORKING PAPER No. $88 / 367$

DECOMMODIFICATION AND WORK ABSENCE IN THE WELFARE STATE

by

GOOSTA ESPING-ANDERSEN, PAUL FARSUND AND JON EIVIND KOLBERG

Gösta Esping-Andersen - European University Institute, Florence Paul Farsund

- University of Bergen

Jon Eivind Kolberg - University of Bergen 


$$
\text { All rights reserved. }
$$

No part of this paper may be reproduced in any form without permission of the author.

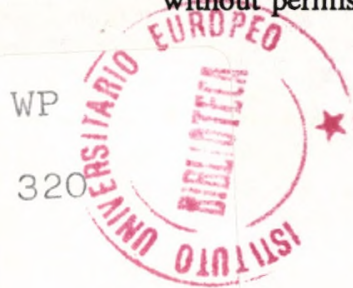

FUR

(C) Gösta Esping-Andersen, Paul Farsund and Jon Eivind Kolberg Printed in Italy in December 1988

European University Institute Badia Fiesolana

- 50016 San Domenico (FI) Italy 
DECOMMODIFICATION AND WORK ABSENCE

IN THE WELFARE STATE

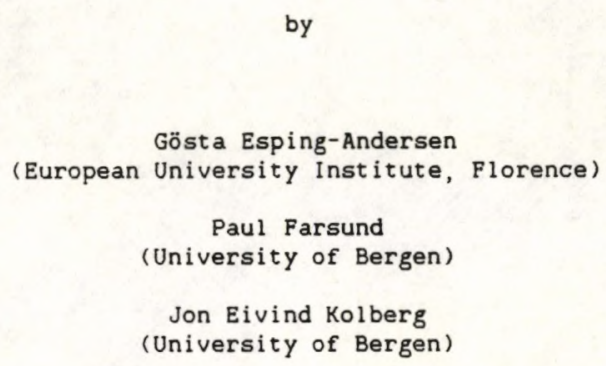




\section{SOCIAL POLICY AND DE-COMMODIFICATION}

Marx' theory of alienation was premised on the argument that capitalist society destroys the connection between man's productive $l i f e$ and $h$ is social being. This theme guided also Polanyi's (1957) analysis of why an economy which is based on the fictitious commodity status of labor is unviable in the long run.

Even within the harshest epoch of laissez-faire capitalism, the pure commodity status of the worker was probably rarely, if ever, fully operational. The concept is better regarded as an ideal-typical construct that in varying degrees was approximated in real life.

Ideal-typically, the pure commodity status entails that a human being has no rights to income or need satisfaction outside the cash-nexus. The market, and not family or community, is thus the ultimate dictator of social choice. Both Polanyi and Marx argued that this kind of subordination of civil society could be upheld only by the assertion of power; as Lindblom (1977) puts it, the pure "free" market assumes, in fact, the status of a prison. The contradiction of such a system is that, if individuals can opt out, they will cease to follow the rules of the cash-nexus; but, if they cannot, civil society will be destroyed. This was the roots of the "social question" that came to permeate late 19 th Century political discourse.

The "social question" was, in reality, a conflict over the extension of social rights in a market economy. It nurtured highly diverse models for social policy. The conservative tradition was, not surprisingly, a pioneer. Both the Church and the "Monarchical Socialists" abhorred 
the idea of self-reliant individualism and naked market competition; they held that hierarchy, authority and the family, not dollars, should guarantee order and efficiency. They could happily embrace a social policy that sustained the family and loyalty to the state.

To the socialists, the abolition of wage labor was, initially, the only realistic precondition for a community of solidarity and rights; their program, therefore, advocated complete de-commodification. And liberalism, finally, sought to formulate a variety of market-conforming social policies with a natural accent on voluntarist, actuarialist, and privately negotiated "rights". Reformed liberalism was willing to extend social protection to the presumably small clientele that was objectively incapable of market participation.

The evolution of social policy in the 20th Century has been patterned around a perennial conflict over decommodification; to what extent and under what conditions should the satisfaction of social needs be fulfilled by citizen rights?

The concept of de-commodification serves to capture the degree to which an individual commands the means to satisfy his social and familial needs independently of the cash-nexus. The concept does not signify an antithesis to the wage labor status; it is a question of the degree to which need satisfaction is divorced from work-compulsion. The central question, then, is when social policies grant the means for de-commodification, how do they in reality influence labor market behavior? In the classical liberal doctrine, efficiency is a function of wage dependency; loosening this dependency will erode the work incentive. Social reformist thinkers 
assume that social security will raise workers' productivity.

Social security programs naturally differ in their potential effects on labor force behavior. Retirement pensions influence, in principle, only the date of employment exit; if they are contingent upon long contributions, they should actually encourage performance. Unemployment insurance mainly affects the duration of job search. Within normal working 1 ife, it is paid work-absence programs that are the most problematic from the point of view of the incentive- and decommodification effect (Danzinger et al.,1981; Salowski, 1980; 1983).

Paid work-absence typically includes (aside from paid vacations) programs covering sickness, maternity, education leave, and sometimes also parental leave, union activities, and the like. They can be regarded as a means to harmonize one's status as worker and citizen by granting the capacity to simultaneously satisfy personal, familial and communal needs within the context of employment. Paid work-absence is potentially decommodifying in that it grants enhanced control to the worker of when, and whether, to work.

Actual work absence behavior is likely to be influenced by a complex combination of available social benefits and socio-economic contingencies. First, the existence of benefits, as such, permit workers to be absent without drastic pecuniary consequences. In turn, their generosity and ease of eligibility is likely to influence the degree to which workers, on the margin, will select for absenteeism. 
Secondly, absenteeism, and certainly sickness-absence, will be influenced by the health risks at work. Industries have widely different degrees of risks with respect to illness, injury and stress. This should influence absenteeism.

Thirdly, the conditions of work and the organization of production are variables that are bound to affect absenteeism patterns. As, for example, Blauner's (1967) classical study suggests, the experience of freedom is a function of production conditions; crafts- and some "high-tech" industries offer significantly greater autonomy than do assembly line factories. In a parallel way, we can assume that some service industries and the public sector will offer greater freedom and capacity for social integration. To the extent workers employ "coping strategies" to counter unpleasant jobs, this may be reflected in absenteeism.

Finally, absenteeism will be influenced by circumstances outside the working environment: personal, familial and community factors. For women workers, the constraints of child bearing and caring are obvious. The "blue-monday" syndrome is an equally noticeable effect of peoples' search for extended leisure time.

This study examines the relation between work-absence policies and absenteeism behavior in three Scandinavian countries over the past decades. As a group, these countries boast some of the world's most liberal absenteeism programs. The menu of benefits covers contingencies with respect to sickness, family obligations, maternity, parental leave, educational leave, participation in trade unions, and of course vacations. As a whole, benefits tend to approximate 
normal worker earnings, waiting days have been more or less abolished, medical certification has been substantially relaxed. Yet, significant variations do exist between the four nations that should affect absenteeism. In Section 7 , we shall examine the role of program characteristics in more detail.

our primary concern is to explore the extent to which patterns of absenteeism reflect de-commodification; i.e. do patterns of absence demonstrate autonomy from the constraints of the market place? Or, do they primarily mirror the anticipated consequences of work and personal problems? In other words, is absenteeism a question of free social choice, or of imposed behavior?

This study will examine absenteeism in relation to a set of economic and "objective" factors most likely to influence absence. First, we will trace the relation of sickness absence to variations in industry-wide health risks. If the relationship is weak, there are grounds for assuming a certain degree of de-commodification.

Secondly, we shall examine the relationship between absenteeism (in its totality) and the disciplinary effects of the economy; if recessions and especially unemployment do not affect absenteeism, one might, again, speak of a certain de-commodification.

Thirdly, we would expect that female absence rates will, independently of other factors, be affected by the rise of women labor market participation. Women have typically higher absence rates due to family- and child care obligations (although the literature sometimes argues the independent effect of women's weaker work-attachment (Salowski, 1980;1983). Put in a marginalist framework, 
the question is whether the cost of maximizing female employment is a marginally higher rate of absence, given the desire to integrate family- and working-life.

Fourthly, early retirement will influence absence, and especially sickness absenteeism. This has, in the past, been a predominantly male phenomenon. Since early retirement will include older and often also disabled workers, it more than 1 ikely will reduce sickness absence rates.

Fifth, we should expect to find a "social policy effect" on absenteeism. In part, we anticipate that, all other things being equal, the degree of program liberalism will positively influence absenteeism. And, in part, we have to consider possible substitution effects between alternative social policy choices facing workers (Aarnio,1982). Thus, if a worker faces the choice between early retirement and sickness absence, it stands to reason that his/her choice will be dictated by the two programs' relative attractiveness.

The study is a macro-level analysis of absenteeism over time and across three nations. It will not test theories of individual behavior. It is important to note that we are not directly addressing the "work-incentive" issue. Neither our problematic, nor our data, permit us to test such hypotheses. The study is rather an attempt to develop a sociology of welfare state-working life interactions. 
The data for all three countries derive from labor force sample surveys. These, unfortunately, are not strictly comparable. The Danish surveys are conducted only once a year (in october), and the reference period is for one day only. In contrast, the Norwegian surveys are quarterly, and Swedish are monthly; both have a one-week reference point. These differences create problems. First, with a one week reference point, it is more likely that the surveys will capture higher absenteeism rates. Secondly, we know that both sickness and vacations are distributed unequally across the year; hence, the Danish data will be biased.

Another source of incompatibility has to do with the detail of reporting. For Denmark, we have information only on sickness absence, while the other nations include information on vacations, family-related, and humancapital related, absence. Furthermore, for Denmark and Sweden we have data only by 1-digit ISIC industrial classification. A 2-digit breakdown is possible for Norway, which helps differentiate the influence of production conditions on absenteeism.

A thind shortcoming of our data is that we cannot differentiate by duration of absence. The findings which we present below, show low correlations between absence and our key independent variables. Had we been able to differentiate long- and short-term absence, the relationships could have been different. For example, a 1975 Swedish study (Eriksen, 1980), based on more detailed individual-level data, shows strong correlations between work environment and long-term absence, something that we do not find with our data. 
A fourth constraint are the different time-frames of the surveys. For Denmark, we have only four years (1975, 1977,1981 and 1983). This prohibits the kind of timeseries analyses that are possible for Norway (1972-1985) and Sweden (1965-1983).

The data base is tables constructed from the surveys. These include the following main variables: persons absent on any given day (week), annually adjusted, by sex, industry ( 1 or 2-digit), by type of absence, by year. In addition, we have data on unemployment by sex and industry (as above), data on female employment growth by industry, and data on male participation among the 5564 year group.

In order to estimate the health risks in different industries, we have utilized the 1983 Norwegian Level of Living Survey's battery of health-risk exposure information. Twenty health-risk items have been averaged for each industry (at the 1-digit or 2-digit level, depending on the country). The items include physical as well as mental health indicators. In constructing this variable, we have assumed, first, that the industryspecific health-risk is fairly constant across the period observed, and that identical industries across nations have fairly similar health-risk profiles.

Finally, some data bias is introduced by the discrepancy between nominators and denominators: absence data are based on all persons in employment (aged 15-74); this includes the self-employed. To calculate absence ratios, however, the denominator includes only employees. A strong bias is not likely to exist in most industries, but in the primary sector (with its large proportion of self-employed), the bias is likely to be so large, that 
we have chosen to omit this sector from our analyses.

Our subsequent analyses will shift between sickness absence and total absence. For Denmark, we have data only on the former, and for Sweden we cannot differentiate the sexes except with regard to the latter. Yet, the shift is basically dictated by theoretical concerns. In analyzing the influence of health risks, the appropriate dependent variable is clearly sickness absence; in analyzing the impact of unemployment and labor market conditions, total absence seems more appropriate since disciplinary effects of the business cycle should influence all kinds of work absence.

\section{THE COMPARATIVE POSITION OF SCANDINAVIA}

Genuinely comparable data on absenteeism are very hard to come by, due to national differences in data collection (surveys, insurance funds, employers), measurement (persons or days lost), and questions asked. One of the few attempts to assemble a fairly comparable overview is the recent OECD (1985) study, which presents over-time data on sickness absence (the easiest to compare) for a range of OECD nations since 1960. The measure of sickness absence is not comparable to ours, since it uses days per year and since it basically relies on employer provided information. It therefore reflects mainly manual workers in industry. Yet, it helps situate the Nordic countries internationally.

The OECD data indicate three clusters of nations. One group is characterized by very high rates of sickness absence (averaging 20 days absent per person/year): Ireland, Belgium, Sweden, and the U.K. (in that order). 
This group is quite a distance from the middle-group (Germany, France, the Netherlands) which averages 12 days; the middle group, again, is far removed from the low group, which includes the United States, Canada, New zealand (and averages about 5 days).

Unfortunately, the OECD table includes only Sweden from the Nordic group. Yet, we can apply American personbased frequencies as a yardstick in order to situate Denmark and Norway within the larger context (Taylor, 1979). On this basis, the Danish rates of sickness absence fall rather close to the low group in the OECD study, while Norway falls in the middle group, and Sweden (as already noted) in the high group. This kind of approximation is, nevertheless difficult; a comparison with the U.S. is especially troublesome since that country has no social programs to distribute cash benefits in case of work absence. Thus, sickness absence data in the U.S. may hide also absence for other reasons, while in the Nordic countries specific alternative absence programs are available.

4. THE MACRO-CONTEXT OF WORK ABSENCE

Cross-national, as well as over-time, variations in absenteeism are likely to be influenced by unemployment and the business cycle. While both Sweden and Norway have enjoyed virtually uninterrupted full-employment (although with a slight growth in the 1980s in some industries), Denmark has suffered from mass unemployment since the mid-1970s. The "disciplinary" effect of the business cycle would therefore be more likely to exert itself in Denmark . 
Two of the most dramatic developments in labor markets over the past two decades have been the exit of older, predominantly male, workers, and the growth of female employment. Among our three nations, the decline in labor force participation among older males has been most dramatic in Denmark, moderate in Sweden, and quite modest in Norway. The growth of female employment has been spectacular, especially in Denmark and Sweden; but it has by and large been confined to public sector social welfare services (about 80 percent of total growth in Denmark and Sweden).

The effects of structural changes like these should be visible. Early retirement should diminish absence within an especially high-risk group (older males). On the other side, a strong growth in female employment should raise absenteeism, perhaps mainly in terms of maternity- and parental leave.

The countries' industrial structure is quite diverse. It is well-known that some industries offer much more arduous, stressful and physically impairing working conditions than others. Industrial composition is therefore likely to affect aggregate absenteeism rates, although less likely to influence rates within

particular industries. One may assume that working conditions in the Nordic countries are fairly similar within identical industries. We should, nonetheless, note the continued prominence in Norway and Sweden of primary sector industries such as forestry and mining; in Denmark, the crafts-legacy is powerful in the very large construction sector (that has also suffered unusually heavy unemployment). And we should note the very large public social service employment in Denmark and Sweden. 
Sickness absence in Denmark is lower than in the other countries. It has hovered at one-or two percentage points below Sweden and Norway, and in contrast to the other nations, it has been declining since the early 1980 s.

Both sickness- and total absence has always been higher for women than men, and the differential has generally grown in all three countries over time. In Denmark, female absenteeism started declining later than among men. In Denmark, female absence has been about 2 percent higher than males on average; in Norway, 2-3 percent; and in Sweden, 3-5 percent.

The trends in Danish sickness absence suggest a break between the 1970 s and 1980s. The zero-order correlation between total sickness absence in the pooled 1975/78 period and in the pooled $1981 / 83$ period is only 299 . However, if we differentiate by sex, we find that the break obtains only for men. The correlation over the two periods for men is a negative -.211, while for women a strong positive .706. We shall later trace the roots of this gender-based divergence.

In contrast, the Norwegian and Swedish absence rates increase smoothly over the period, with a levelling-off in the 1980s. Broken down by gender, we find that Norwegian males are quite stable while women's absence grows; Swedish men show a small decline in the 1980s.

The comparably low, and declining, Danish absenteeism is interesting because it suggests the validity of several contending hypotheses. On one side, one may explain the 
comparably low incidence as a function of the Danish employer-financing period of eight weeks. The employer fiscal responsibility $\mathrm{might}$ induce management to exercise greater control. On the other side, the declining trend might be explained, alternatively, by the introduction of waiting days in 1982 , by the high unemployment rates, or by early retirement. In the following, we shall attempt to isolate the causes.

\section{HEALTH RISKS AND ABSENTEEISM}

Industry-related health-risks should mainly influence sickness absence. In our countries, the highest risk scores are found in mining, construction, agriculture/ fishing, manufacturing and utilities (in that order). The lowest scores are found in banking/insurance, social/ private services, and wholesale/retail trade (in that order).

The relationship between absenteeism and health-risks varies noticeably across nations. In Denmark, the most remarkable finding is the opposite distribution of men and women. As we can see in TABLE 1, female sickness-absence is indeed strongly negatively related to health risk. This means that women in the services, retail and in bankinginsurance industries are much more absent than women in the risky industries. In fact, an inspection of the residuals shows that women in the banking- and services sector are doubly more absent than the model would predict.

For Danish men, the pattern is the opposite: they are most absent where risks are the highest. Yet, the strong association we find for Danish men evaporates by the 1980s. 
It is possible that the disappearance of a positive correlation for Danish men in the 1980s is explained by either the unemployment-effect or the early retirement effect. The residuals show that male absence rates have declined most dramatically in the high-risk industries: construction and in manufacture. These same industries have also experienced the greatest degree of unemployment and early retirement. Yet, in separate tests for the effect of unemployment (see below), the plausibility of such an explanation becomes doubtful. Nonetheless, the net effect, over time, is that male absenteeism in Denmark has become homogeneous across industries.

\section{TABLE 1 HERE}

There is a much more similar pattern of behavior among the sexes in Norway. As shown in Table 2, there is a consistent positive correlation between health risk and absenteeism among Norwegian males. There is, unlike Denmark, no particular alteration in the patterns over time. An inspection of the residuals shows that absence is much higher than predicted in textiles. The lack of an industry-rationalization effect in Norway may be inferred from the finding (not shown here) that controlling for early retirement of older male workers does not affect the correlations between absence and health risk. However, unemployment significantly affects sickness absence in the late 1970s and 1980s. For 1978 and 1985, a control for unemployment lowers the explanatory value of health risks (but does not render it insignificant).

For Norwegian women, on the other hand, there is a consistent lack of association between health-risks and sickness. But, the pattern is far from the powerfully negative Danish relationship. In contrast to Denmark, the 
residuals show that Norwegian women are not especially absence-prone in the service sectors;they tend, by and large, to behave like their male co-workers.

For Norwegian women, a control for FEMPART (female employment change) does not affect the lack of a health risk effect. Female employment growth is insignificant except for the 1980s; for 1985, the $B$ coefficient is$.024(t=-2.01)$, and it adds about 10 percent to the explained variance. For Norwegian women, unemployment does not affect sickness absence.

\section{TABLE 2 HERE}

The Swedish sickness-absence data cannot be broken down by gender. This presents a problem since we know from Denmark that the sexes can behave in exactly opposite ways. In any case, it is evident that health risks play a much stronger role in absenteeism. For the entire 21 years, 1965-85, the zero-order correlation is consistently strong (averaging .500-.600). The health risk variable is systematically stronger than in either Denmark or Norway. See Table 2.

To test for gender-effects, one possibility is to examine the residuals for female-heavy industries (public sector and services). Indeed, these residuals do suggest a tendency towards higher than expected absence, but in no manner as dramatically as in Denmark. The other possibility is to examine the impact of health risks on total absence (of which sickness accounts for less than 50 percent). In this case, a logic more similar to the Danish emerges: men are more responsive to health risks, while for women there is no relationship. 
We would have to conclude that, overall, health risk factors do not play a major role in accounting for sickness absenteeism; in particular among women workers. On this count, Denmark clearly appears the most "decommodified".

The health risk-absenteeism relationship provides a very indirect way of testing de-commodification hypotheses. Our measure includes both short-and long-term absence; the latter presumably genuine and serious illness. A better test would have been to examine solely short-term absence data. Still, it can be presumed that the ratio of long-term ill is fairly constant across the years. In this way, the variations we identify can, perhaps, be ascribed to fluctuations in short-term absence.

\section{ABSENTEEISM AND LABOR MARKET EXIT/ENTRY}

As already noted, unemployment levels have been quite different in the three countries. In Denmark, unemployment rose sharply around 1974-75, and has remained high ever since; following 1979-80, unemployment levels jumped still higher. During the 1970s, unemployment was about $7-8$ percent in construction, and about 10 percent in manufacturing. By the 1980's, unemployment was almost 30 percent in construction, with about 15 percent in manufacturing. In the services and in the public sector, however, unemployment has always been negli geable. 1

In comparison, unemployment has been consistently low in

t. Note that these unemployment figures are
calculated as a
the total labor force.


Norway and Sweden, and differences between industrial branches have been far less pronounced. In Sweden, the highest rate of unemployment is recorded in the hotel/ restaurant trades (about 6 percent in the 1980's). In manufacture, mining and construction, unemployment hardly ever exceeded 3 percent. As in Denmark, there has been no real unemployment in the services. The Norwegian pattern is very similar to the Swedish. Textiles is one of the few sectors with some unemployment (female unemployment climaxed with 8.6 percent in 1984), and above average rates are recorded in "other manufacturing" and hotels/restaurants, mainly in the 1980's.

Unemployment can affect absenteeism by its direct or indirect disciplinary effect. On one side, employers are probably more likely to lay off frequently absent workers; on the other side, the risk of unemployment may exercise a general discouraging influence on absenteeism. A symptom of de-commodification would be when absence appears insensitive to such disciplinary forces. This should be observable across industries with different levels of unemployment, and across the business cycle.

A disciplinary effect ought to hold strongest for Denmark, not only because of that country's much higher unemployment rates, but also because the active labor market policies that would cushion individuals' risk of unemployment are far inferior to those existing in Sweden.

The labor force exit of older males and female employment growth are likely to influence absenteeism behavior, too. As we discussed in the section on health risks, male early retirement should lower absenteeism due to the likelihood that old workers are the most absent prone. In contrast, female employment growth should increase female 
absence. We shall, as far as the data permit, include these variables in the following models.

Our analyses must proceed in two ways. We begin with cross-sectional analyses, due to the unavailability of time-series data for Denmark. We then turn to a timeseries approach for Norway and Sweden, where we contrast over-time patterns of high- and low-unemployment industries.

For Denmark, the OLS-models indicate that there is no single year in which there is a positive (or even statistically significant) effect of unemployment on (sick-) absence. This holds for both men and women. The most surprising result is that there is no observable change in the patterns of the 1970's (when unemployment was still modest), and in the 1980's. The zero-order correlations between unemployment rates and sickness absence are invariably close to zero (the one exception is for women in $1975 ; r=.375)$. The residuals also fail to support any hypothesis concerning industry-specific disciplinary effects. See Table 3 .

TABLE 3 HERE

For Denmark, there would appear to be an effect of male early retirement, although data limitations prevent us from testing this directly. In the aggregate, male absence falls sharply at the time in which early retirement begins to take-off. However, female employment growth (FEMPART) has no effect on absenteeism among women. For no single year is there a significant relation. Here, we must remember that the lion's share of female employment growth has occurred in the public sector where, also, absence is much higher than the model 
would predict.

In sum, for Denmark it is difficult to identify much of an effect of labor market conditions on absenteeism. Unemployment is certainly irrelevant, and while early retirement may lower male sickness rates, female employment growth has no direct effects.

For Norway, our cross-sectional analyses show surprisingly different results (see TABLE 4). Over the entire period, 1972-1985, unemployment does not significantly affect sickness absence, but it is a significant and generally strong predictor of total absenteeism among men and, from the late 1970's onward, also for women. But, the direction of causality is completely opposite to what we would have expected from a "disciplinary" type hypothesis, because absence rises with unemployment. Unemployment explains about 30-40 percent of the variance in male, and 10-20 percent in female, (total) absenteeism rates. The residuals tend to confirm the positive relationship. In some industries with fairly high unemployment, absenteeism is far higher than expected. When we control for the health risk variable in the model (not shown in Table 4), the effect of unemployment is not reduced; instead, the total variance explained is increased. Both variables have a significant influence on absence independently of one another.

For Norway, the data also permit us to directly control for the impact of early retirement and female employment. Early retirement plays no role in male absenteeism during the 1970's, but does begin in the 1980's to show a marginal effect. For 1985, when entered as a regressor with unemployment $(B=.095 ; t=1.86)$, it adds about 4 percent to the variance explained. That early retirement 
affects male absence positively is odd, but then the coefficient is both very small and hardly significant.

\section{TABLE 4 HERE}

Table 4 suggests that Sweden is, surprisingly, the only country in which a disciplinary type hypothesis seems to obtain. But then the reduction of absenteeism due to unemployment occurs only among women, and only in the "full employment" era. By the 1980's, the relationship disappears. In contrast, Swedish men are systematically insensitive to the unemployment effect. An examination of the residuals does not clarify these seemingly contradictory results; there is no visible pattern of under- or over-prediction by individual industries for either of the two sexes. The most likely explanation of women's declining sensitivity to unemployment is their growing concentration in public sector and service jobs, industries in which unemployment is practically nil.

A first conclusion that presents itself when we review the effect of unemployment, is that all three countries have by and large severed the traditional behavioral response to the fear of unemployment. The data suggest that women have, in this respect, entered a decommodified status later than males. We may here speculate that the effect is due to the shift in female employment from traditionally vulnerable industrial jobs to welfare state jobs, and probably also to the evolution of job protection legislation that emerged in the 1970's in all three countries.

Nevertheless, the cross-sectional analyses presented above are not well-suited to testing hypotheses of overtime behavioral responses to the business cycle. By 
shifting to a time-series analysis, we are not only able to infer period-effects, but also to compare behavioral responses in particular industries. We would thus like to compare the effect of unemployment on absence in industrial branches with high- and low unemployment, and with high- and low male/female concentrations.

A time-series approach is feasible for Norway and Sweden. For Norway, the data cover a 14-year period (1972-85), broken down into 28 detailed 2-digit ISIC industry groups. For Sweden, the time-series covers 20 years (1965-83), by 10 1-digit level industries.

For Sweden, we ran the following model for each of ten industrial branches; for males:

(1) TOTABS $=b(c)+b($ UNEMPLOY $)+b($ OLDPART $)+e$, where OLDPART is change from previous year in the participation of older male workers. And for women:

(2) TOTABS $=b(c)+b($ UNEMPLOY $)+b($ FEMPART $)+e$, where FEMPART is change from previous year in the participation of women.

These models should permit us to test two arguments simultaneously. First, whether the disciplinary effect of unemployment obtains over business cycles; secondly, whether the exit of older workers reduces (male) absence and, vice versa, whether growth in female employment raises the marginal propensity of women to be absent.

The results for Sweden are shown in Table 5. For the male sample, the models where strongly autocorrelated in mining/manufacturing,

the auto-industries, and in construction. The zero-order 
correlations in these industries, however, suggest a positive relation between unemployment and absence, and a substantially negative impact of early retirement. For the males in Table 5, we present two industries with low unemployment: ISIC 6 (retail/wholesale) and 8 (finance/insurance); and two with higher unemployment: ISIC 5 (hotels/restaurants) and $\rightarrow$ (personal and recreational services). Notice that model 6 is vaguely autocorrelated.

For the female sample, the models were autocorrelated within manufacturing/mining, automobiles, construction, and retail/wholesale. We present for women in Table 5 two low unemployment industries: ISIC 8 (finance/insurance) and 10 (social- and related services - essentially public sector); and two higher unemployment industries: ISIC 5 (hotels/restaurants) and 9 (personal and recreational services).

TABLE 5 HERE

While none of the models presented in Table 5 are autocorrelated, or at least not strongly so, it is important to note that one of the models (ISIC $q$ for males) suffers from multi-collinearity: OLDPART and UNEMPLOY are mutually strongly correlated $(-.817)$. This means that we shall refrain from interpreting this model.

Still, the general pattern suggests that unemployment has no disciplinary effect on either men or women in Sweden; on the contrary, the tendency is for absenteeism to rise as a result of unemployment. This holds for both low- and high-unemployment sectors; both manual and non-manual industries; and both the private and public sector. The only exception is for men in the low unemployment 
sectors, but the coefficients are not significant.

Table 5 also contradicts our findings from Table 4. The cross-sectional analyses of Sweden showed a negative impact of unemployment; the time-series show a positive impact. How may we explain this? A first supposition would be that the unemployment effect is mediated by changes in labor force participation (OLDPART or FEMPART); yet, separate estimates (not shown here) show this not to be the case: the independent effect of unemployment is not affected. Instead, the most plausible answer has to do with the different logic of chronological behavioral characteristics of workers. One such element is the powerful trend effect: in many industries, both absence and unemployment have grown linearly over time -- this accounts for the strong autocorrelation effects in several of our models. Another, is that workers react to changing labor market conditions differently than they do to relative conditions at any given time. For example, the positive over-time effect of unemployment may simply reflect industries' strategies of labor hoarding in slack times. Since, in Sweden, the costs of absence are shouldered by the public sector, absence programs may very well provide a convenient vehicle for work-time reduction.

The decline of labor force participation among older workers shows contradictory effects. In retail/wholesale, it raises absenteeism; in personal services, the effect is negative (but recall the problem of multicollinearity). However, when we enter OLDPART alone in the model, its effect on absenteeism is strongly negative in personal services $(B=-.582 ; t=-7.04)$.

The most surprising finding is that female employment 24 
growth significantly reduces absenteeism. In light of the strong effect in ISIC 10 (public social services), where female employment has grown most, the evidence clearly contradicts the argument that absenteeism is the price to pay for adding the additional woman workers to the labor force.

For Norway, the time-series is too brief to include more than one regressor in the models. We can therefore not test the simultaneous impact of OLDPART/FEMPART. The unemployment trends in Norway are, for most industries, basically low and stable. Among the few industries with significant unemployment growth are "other manufacturing", and hotels/restaurants (for the male sample). These models are not autocorrelated, but in neither case is the effect of unemployment on (total) absence significant. There is, however, a small positive (but insignificant) effect of unemployment on absence-as we found in sweden. Among the low unemployment industries in Norway (metals, machines, insurance, business, banking, public services) the only significant effect of unemployment (in the male sample) is found in public sector social/health services. Surprisingly, the effect is negative.

Among the Norwegian males, there are absolutely no indications that exit of older workers affects absenteeism, either alone or together with unemployment; the coefficients are systematically tiny and insignificant. This is what one would anticipate in a country where early retirement has been only of modest proportions.

For the Norwegiąn female sample, high unemployment industries include textiles, "other manufacturing", 
hotels/restaurants, and personal services. None of these models are autocorrelated, but the effect of unemployment is insignificant for textiles and personal services. In contrast, unemployment has a significant effect for "other manufacturing" and hotels/restaurants. Among the low-unemployment industries are retail, finance, insurance, and public services. Among these, retail and public services are significant and not autocorrelated. See TABLE 6 .

The FEMPART variable (growth in female labor force participation) is systematically insignificant with respect to female absence. There are no indications that changes in female employment influence female absenteeism over time in any single industrial branch.

\section{TABLE 6 HERE}

In Norway, then, the impact of unemployment on absenteeism is quite contradictory: negative for women in the private sector and strongly positive for women in the public sector; in turn, it is negative for men in the public sector, but non-existent in the private sector.

To a degree, these contradictory patterns confirm previous findings; that is, women in the private sector tend to be quite responsive to disciplinary effects -- or economic uncertainty -- while their public sector equivalents seem wholly immune to market forces. Similar patterns prevail in Sweden and Denmark, something that leads us to conclude that, systematically in Scandinavia, the public sector plays the role of a vanguard of (female) worker de-commodification.

Yet, the evidence seems in general to point towards $26^{\circ}$ 
strong de-commodification effects in all three countries, for both sexes, and across types of industries. If we can assume that variables such as unemployment capture the operation of market forces, we will have to conclude that the trend is towards a substantial de-coupling of absenteeism from the market logic.

If, then, neither objective health risks, nor market forces, significantly explain work absence, is it possible that behavioral patterns are dictated by the social policies of the welfare state? Has the welfare state increasingly come to be a central organizational principle in the patterning of modern working life? It is to this question that we now turn.

8. THE SOCIAL POLLICY EFFECT

The large literature on work disincentives often argues that a guaranteed "social wage" will reduce work effort. If it is true that people respond to social policy and not to labour market conditions, this would entail: (1) that absence behavior would be greater in the countries with the most generous programs, and (2) that absence behavior would change with changes in legislation, independently of prevailing labour market conditions.

Thirdly, the welfare state's influence on absenteeism will clearly depend on the different social wage options which are available for similar groups of clients.

\section{1. Program Generosity}

A key idea from the point of view of both work disincentives and de-commodification is that the demand for, 
and utilization of, program benefits is a function of their level of generosity. Over the past twenty years in our three countries, there is a clear trend towards greater generosity in sickness insurance, unemployment insurance, early retirement programs and maternity benefits. In Table 7 , we present a composite measure (explained in the Appendix) which captures changes in the attractiveness of sickness insurance in the three countries. It summarizes compensation levels, waiting days, contribution periods, duration, coverage and one aspect of the private-public mix (employer period).

\section{TABLE 7 HERE}

In each country, sickness benefits have become more 1 iberalized over the period 1965-1985. The Swedish system is clearly the most generous. But, the programs have not always experienced a continuous linear growth. The Swedish system is stable; the Danish became slightly more restrictive in the 1980's. Since, however, the overall trend is towards liberalization, a dis-incentive argument would lead us to expect that sickness absence would rise in all nations.

8.2. The Relative Attraction of Sickness Insurance.

As a rule, studies of the postulated disincentive effects of the welfare state have concentrated on one program (such as sickness insurance) without simultaneously considering other programs. But it is likely that the program mix, too, matters in terms of benefit consumption; the relative attraction of a specific program (like sickness insurance) as compared to other, related programs ( 1 ike unemployment insurance or early 
retirement) has an impact upon the choice of prospective clients. We can assume that people often have the capacity to choose between different programs, and that their choices will reflect an assessment of the pros and cons among the alternatives.

Our second program attribute, therefore, speaks to the relative attraction of sickness insurance as compared to (i) unemployment insurance and (ii) medicalized early retirement. If program characteristics shape workers' behavior, we would predict that sickness absence grows in line with its attractiveness compared to rival social programs. In Table 8 , we present a summary measure which describes net compensation differentials between sickness insurance, on one hand, and unemployment insurance and medicalized early retirement, on the other hand (For technical specifications, see Appendix). A score of 1 depicts a situation of identical net compensation; a score below 1 refers to a situation in which sickness insurance compensates less of the lost salary than does an alternative program in the comparison.

\section{TABLE 8 HERE}

The trend is towards increasing relative attraction on the part of sickness insurance. This is especially so in Denmark where we, therefore, should expect a rise in sickness absenteeism. In Norway, sickness insurance has improved compared to unemployment insurance since 1970, and less so compared to early retirement. Here, too, we would then expect a rise in sickness absenteeism. In Sweden, sickness insurance has always held the comparative advantage, and there are no clear-cut patterns of change. 
8.3. Program Differentiation.

A third possibility is that the proliferation of program options for paid work-absence has an impact on the volume of specific types of absence. Ceteris paribus, we would expect the pressure upon sickness insurance to decline when other programs and options (say, maternity leave or other kinds of family related absence) come into existence.

To capture the total structure of absence, we have calculated sickness absence as a fraction of total absence over time. See Table 9 . Unfortunately, such data are available only for Norway and Sweden.

\section{TABLE 9 HERE}

The Swedish structure of absence has clearly changed as sickness absence has declined relatively. In Norway, sickness absence plays a greater role in relative terms, but the trend is nonetheless similar to the Swedish. We also notice that sickness absence is less important for women than men.

\subsection{Analysis}

The following analysis cannot rely on statistical techniques. Instead, we will rely on visual inspection to determine the degree to which sickness absence is related to social policy characteristics.

The cross-national patterns of sickness absence shown in Graphs 2-5 yield somewhat ambiguous results. The consistently very high absence rates in sweden seem to 
lend support to the program-characteristic-effect argument: Sweden's absence rates and program generosity are both the highest, regardless of industry-group. Yet, a comparison between Denmark and Norway points in the other direction; the graphs show that absence is consistently higher in Norway, despite the fact that Norwegian program attraction levels are similar to the Danish. This holds for all industries and virtually all years. However, it is possible that Denmark's lower rates reflect the presence of a two-week employer period of financial responsibility. Having to shoulder the costs of absenteeism themselves, employers are likely to monitor absence more closely.

The lack of fit between program characteristics and absenteeism is even clearer when we examine over-time country profiles more closely. In Denmark, sickness benefits improved substantially between 1965 and 1985 (albeit with a small decrease in the early 1980's), but Danish sickness absence rates have been declining steadily (or, at least, have been stagnant) since the early 1970's. As can be seen in Graphs 2-5, this is true for the economy at large (ISIC 2-9), and for select industrial branches. Although not shown here, genderspecific data show that the declining trend holds for men as well as women.

The decline in Danish sickness absence is the more puzzling when we also consider the relative improvement of sickness benefits over alternative social policies. The only visible "social policy effect" for Denmark is that absenteeism declines with the reduction of sickness benefits in 1983. But even this association may be spurious since the decline in absence is a long term trend. For Denmark, then, there is very little basis for 
a direct "social policy" effect.

For Sweden, the long-run trend in benefit-generosity is very stable, and sickness benefits have consistently maintained a relative advantage compared to either unemployment- or early retirement benefits (although unemployment benefits improved relatively in the 1970's). In Sweden, the most important structural change has been the relative decline of sickness in total absenteeism. Taken together, these institutional features should not point towards a general rising trend in sickness absenteeism; yet, that is exactly what happened in Sweden. The trend is cyclical, with a growth from 197278, followed by a slight decline until 1983, and then a renewed period of growth. If the relative improvement of unemployment benefits should have lowered sickness absence, it would have had to happen in the early 1970's; yet, it did not. And it is also clear that the proliferation of alternative absence programs has not led to a decline in sickness absence rates. As for Denmark, then, there is no clear-cut "social policy" effect for Sweden.

For Norway, program changes would have led us to anticipate a major growth in sickness absence during the 1970's (especially after 1975), followed by a levellingoff from 1980 onwards. Program generosity, both in absolute and relative terms, rose considerably between 1970 and 1980, stabilizing thereafter. In Norway, the structure of absenteeism remained fairly stable over the period.

Nonetheless, also the Norwegian absence data confirm the general lack of a direct "social policy" effect. The trends we observe in Graphs 2-5 do not show the 
anticipated $r i s e$ in sickness absence over $t i m e$, be it at the aggregate or dis-aggregated industry-level. Nor are there marked differences between the sexes (not shown here). The only industry in which there is a consistent rise of sickness absence is in health, education and welfare. But it is difficult to ascribe this to social policy variables. The strongest growth was in the 1980's, not when benefit improvements occurred; and, if we examine the trends more closely, we note that women in education show a constant rate of absence until 1983, while in the health sector, female absence grows systematically over the entire 1980's. It is only in welfare services that absence trends seem to conform to program changes.

In summary, the evidence (however crude) does not lend much support to a "social policy" effect thesis. Among the few plausible candidates are: one, the coincidence of high benefits and high absence in the Swedish case; and, two, the systematically lower levels of absence in Denmark, which may reflect the presence of an employerfinancing period. But, the contradictory evidence seems much more powerful, in particular the fact that in no country do sickness absence rates follow trends in legislation.

To base any conclusions on this level of generality is haphazard, but there clearly is no consistent relation, either over time or across nations, between program attraction and absence.

\section{CONCLUSIONS}

Our study has found a fairly remarkable presence of decommodified labor market behavior in the Nordic 
countries, at least with regard to work-absence. That is, people do not seem to follow the dictates of working life as it is traditionally organized in capitalist markets. Unemployment and job-insecurity which arises from business cycles seem to have no influence whatsoever on a person's propensity to stay away from the job. In this sense, the market appears to have lost much of its presumed disciplinary capacity. Objective health risks show, in a parallel way, a declining effect on sickness absence.

A straightforward welfare state/work-disincentive theory does not appear to explain de-commodified behavior. The "social policy" effect is marginal at best; workers do not automatically respond with more absence when the welfare state offers more lucrative means for doing so. This, it should be noted, does not imply that social policy has no effect. Absence might very well be dramatically lower if benefits were highly unattractive. The social policy effect may be understood in terms of a threshold: when benefits offer a certain minimally acceptable level, absence may very likely grow. But, beyond that it is difficult to identify further effects.

The actual absenteeism patterns we find are, in a sense, unexplained by reference to the direct effects of standard variables. Nonetheless, a number of our findings point towards the operation of highly complex interaction effects that are difficult to identify precisely with the $k$ ind of data available here. We may, therefore, conclude with a set of strong hypotheses that emerge from our analyses.

One first such hypothesis is the growing sectoral bifurcation that coincides with the rise in women's labor 
force participation. The de-commodification effects we have found are strongest and most systematic among (female) public sector employees, and considerably weaker among both male and female private sector workers. In fact, the behavioral characteristics of public sector workers seems to have a logic of their own that increasingly contrasts the rest of the labor force. It is, however, not warranted to conclude that women in the public sector are absent without reason. It is possible, for example, that the health-risk indicators we utilize are insensitive to the $k$ inds of stress and fatigue that permeate welfare state jobs. And, being so heavily female concentrated, there is little doubt that the welfare state sector will give rise to exceptional absenteeism rates due, for example, to family responsibilities. And, thirdly, welfare state jobs may easily serve as a magnet for a peculiarly absent-prone clientele. They normally offer greater job security, flexibility, part-time employment, and may therefore appeal to that particular group for which absenteeism is most likely: single mothers, for example.

At any rate, one of our most challenging results is the extent to which the public sector deviates from the private economy. As we suggested earlier, the welfare state does seem to pattern working 1 ife. But not so much by its transfer programs as by its role as employer. The welfare state may very well be a vanguard of future labor market trends; but it may equally well be nothing more than a haven in a somewhat more heartless world, to paraphrase Christopher Lasch.

A second hypothesis that emerges from our analyses is the possibility that work-absence follows a very complex structure of interaction effects that renders any search 
for simple relations futile. This is, perhaps, best illustrated for Denmark where early retirement in the traditional industries almost certainly coincides with the decline in absenteeism, but only under very structured conditions: an era of fast-paced rationalization, facilitated by special government programs to permit redundancies via retirement. But, it can also be illustrated for Sweden and Norway, where we found that unemployment has a strong positive effect on absence. Here, a likely interpretation is the coincidence of job-guarantees, welfare state financed absenteeism, and employer labor-hoarding strategies that, together, conspire to "encourage" absence in the want of work.

At present, the only safe conclusion is that much still needs to be done if we are to develop a sociological alternative to the economics of welfare state workdisincentives. 
TABLE 1. THE INFLUENCE OF HEALTH RISKS ON SICK-ABSENCE IN DENMARK. OLS-ESTIMATES.

( $t$-statistics in parentheses)

$\begin{array}{lccc}\text { 1975/1979: } & \text { MALES } & \text { FEMALES } & \text { TOTAL } \\ r & .685 & -.676 & .325 \\ \text { Constant } & 2.21 & 11.1 & 4.96 \\ & (1.32) & (4.42) & (2.59) \\ \text { HRISK } & .178 & -.261 & .074 \\ & (2.49) & (-2.43) & (0.91)\end{array}$

ADJ . $R$

Squared

.394

.380

.022

F Statistic

6.20

5.90

.83

1981/1983:

r

$-.383$

$-.636$

$-.645$

Const ant

$$
\begin{gathered}
4.02 \\
(6.24)
\end{gathered}
$$

13.58

8.13

(4.18)

(4.95)

HRISK

$-.030$

$-.303$

$(-2.18)$

$-.157$

$(-1,10)$

$(-2.23)$

ADJ. R

Squared

.025

.319

.333

F Stat.

1.20

4. 75

4.99

Source: Nordic WEEP Data Bank 
TABLE 2. SICK-ABSENCE AND HEALTH RISKS IN NORWAY AND SWEDEN. OLS ESTIMATES.

( $t$-statistics in parenthesis)

$\begin{array}{cr}\text { Men NORWAY } & \text { SWEDEN } \\ \text { Women } & \text { Total }\end{array}$

(a. 1970 *):

$$
r
$$

C

.205 .358

$$
\begin{gathered}
2.48 \\
(2.05)
\end{gathered}
$$$$
\text { 3. } 29
$$$$
(2.39)
$$$$
\text { (5.49) }
$$

HR I SK

$$
\begin{array}{r}
.104 \\
(1.83)
\end{array}
$$$$
\text { (1.07) }
$$

ADJ.R

Squared .080 .005 .097

F

(3.35)

(1.14)

$1976 / 78 *)$ .457 .197 .263
C
1. 57
(1.31)

2. 70

(2.35)

3. 12

(3.12)

HR I SK

.100

.054

(1. 78 )

(1.00)

.127

(2.05)

ADJ.R

Squared

.074

.000

.263

F

(3.16)

(1.01)

(4. 21)

1983/85*)

C

.407

.345

.488

2. 48

(2.13)

1.48

(.64)

2.60

(1.88)

HR I SK

$$
.124
$$

.204

(1.88)

.115

$(1.58)$

ADJ.R Squared .133

.071

(3.52)

.143

(2.50)

Source: Nordic WEEP Data Bank

*) The years differ slightly for the two countries. For Norway, we have used 1972,1978 , and 1985, as years representative of the period; for Sweden, 1965-67 (pooled), 1976, and 1983 are considered representative. 
TABLE 3. ABSENTEEISM AND UNEMPLOYMENT IN DENMARK. OLS-EST IMATES.

( $t$-statistics in parentheses)

$\begin{array}{lcc}\text { 1978: } & \text { Men } & \text { Women } \\ r & .121 & .103 \\ C & 2.02 & 2.58 \\ & (1.56) & (1.40) \\ \text { UNEMPLOY } & .085 & .079 \\ \text { ADJ.R } & (.32) & (.27) \\ \text { Squared } & .000 & .000 \\ \text { F } & .10 & .07 \\ \text { 1983: } & & -.173 \\ \text { r } & -.113 & 3.48 \\ \text { C } & 2.01 & (2.02) \\ & (4.95) & -.054 \\ \text { UNEMPLOY } & -.008 & (-.47) \\ \text { ADJ.R } & (-.30) & .000 \\ \text { Squared } & .000 & .22 \\ \text { F } & .09 & \end{array}$

Source: Nordic WEEP Data Bank 
TABLE 4. TOTAL ABSENCE AND UNEMPLOYMENT IN NORWAY AND SWEDEN. OLS-ESTIMATES.

( $t$-statistics in parenthẹses)

\begin{tabular}{|c|c|c|c|c|}
\hline & & IAY & & EN \\
\hline & Men & Women & Men & Women \\
\hline $1969 / 1972$ & & & & \\
\hline$r$ & .433 & -.254 & -.233 & -.829 \\
\hline C & 5.20 & 10.56 & 13.46 & 16.94 \\
\hline & $(3.36)$ & $(8.18)$ & $(6.56)$ & $(22.38)$ \\
\hline UNEMPLOY & 3.657 & -.702 & -.891 & -1.380 \\
\hline & $(3.70)$ & $(-1,34)$ & $(-.63)$ & $(-3.92)$ \\
\hline ADJ.R & & & & \\
\hline Squared & .319 & .028 & .000 & .642 \\
\hline $\mathrm{F}$ & $(13.67)$ & $(1.79)$ & $(.40)$ & $(15.35)$ \\
\hline 1978: & & & & \\
\hline$r$ & .679 & .452 & .098 & -.669 \\
\hline C & 3.28 & 8.50 & 14.96 & 20.25 \\
\hline & $(2.52)$ & $(7.78)$ & $(8.47)$ & $(12.88)$ \\
\hline UNEMPLOY & 3.532 & .637 & .233 & -.959 \\
\hline & $(4.72)$ & $(2.59)$ & $(.26)$ & $(-2 \cdot 38)$ \\
\hline ADJ.R & & & & \\
\hline Squared & .441 & .174 & .000 & .369 \\
\hline $\mathrm{F}$ & $(22.28)$ & $(6.68)$ & $(.07)$ & $(5.68)$ \\
\hline $1983 / 85 *$ & & & & \\
\hline$r$ & .525 & .389 & -.106 & -.034 \\
\hline C & 5.72 & 9.99 & 15.02 & 18.99 \\
\hline & $(4.02)$ & $(7.19)$ & $(7.98)$ & $(18.62)$ \\
\hline UNEMPLOY & 1.850 & .775 & -.150 & -.017 \\
\hline & $(3,15)$ & $(2.15)$ & $(-.28)$ & $(-.09)$ \\
\hline ADJ.R & & & & \\
\hline Squared & .248 & .119 & .000 & .000 \\
\hline $\mathrm{F}$ & $(9.89)$ & $(4.64)$ & $(.08)$ & $(.01)$ \\
\hline
\end{tabular}

Source: Nordic WEEP Data Bank

*)For Sweden, the years are 1969, 1978 and 1983; for Norway, 1972,1979 , and 1985. In both cases, these years have been selected as being representative for the periods: a) pre-1973; b) late-1970s; and c) 1980s. 

FORCE PARTICIPATION AND ABSENTEEISM IN SWEDEN GLS-ESTIMATES.

( $t$-statistics in parentheses)

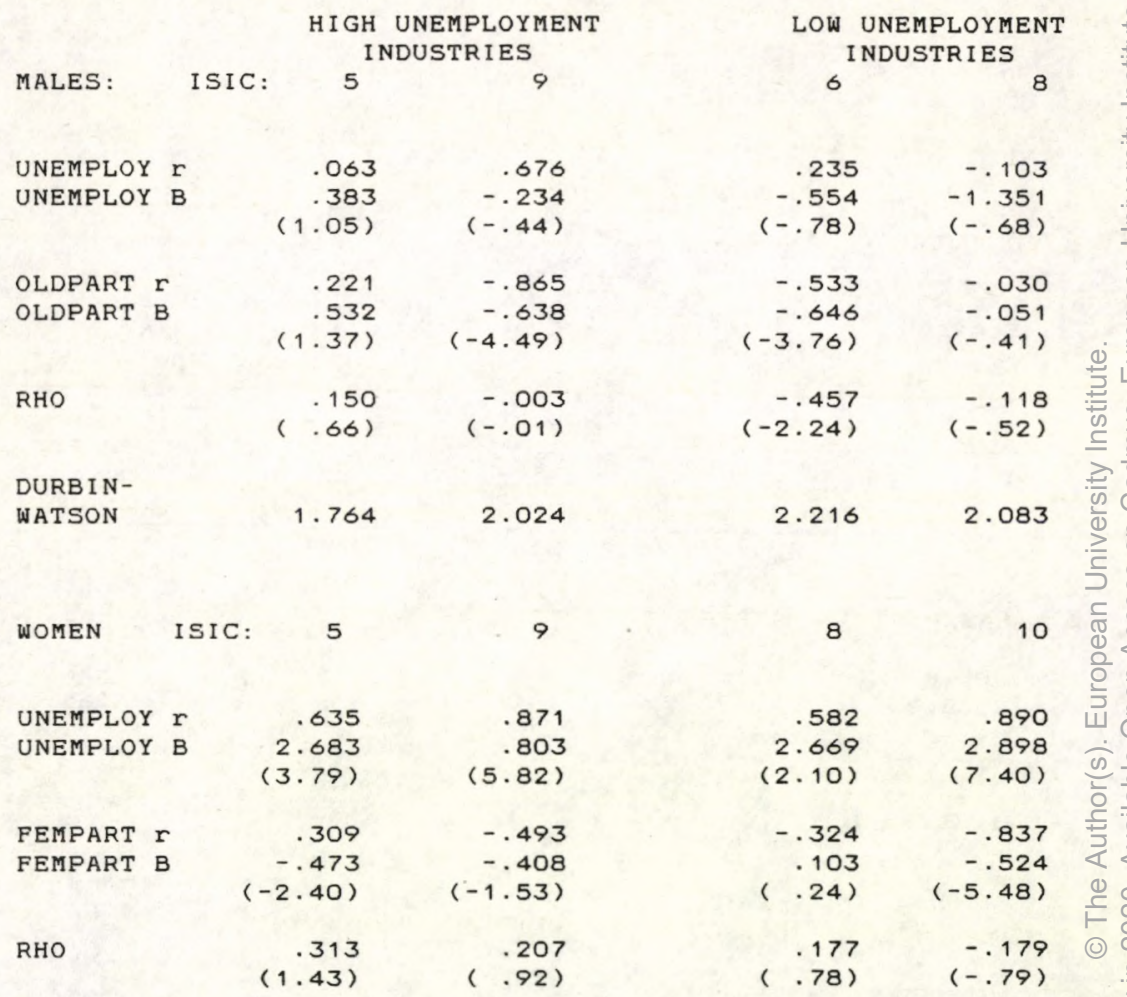

DURBIN-

WATSON

1.774

2.019

1.967

2.310

Source: Nordic WEEP Data Bank.

Note: time series for computations $=1966-1985$. 
TABLE 6 .

THE RELATIONSHIP BETWEEN UNEMPLOYMENT AND (TOTAL) ABSENTEEISM IN NORWAY. GLS-ESTIMATES. (t-statistics in parentheses)

HIGH UNEMPLOYMENT

Men Women

ISI C*)

(39)

UNEMPLOY $r$
UNEMPLOY

.071
.151
$.42)$

RHO

.154
$(.56)$

2.062

1.697

DURBI NWATSON
LOW UNEMPLOYMENT Men

(93)

Women

(93)

(39)

$$
\begin{array}{r}
-.542 \\
-.922 \\
(-2.13)
\end{array}
$$

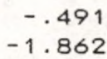

.768

.862

4.025

$(-1.87)$

(4.01)

$-.215$

.027

(1. 302

$(-.76)$

$(.10)$

ic WEEP Data Bank

Source: Nordic WEEP Data Bank

Note: *) ISIC 39 is "Other manufacture", and ISIC 93 is Public sector social/health/education services. 
TABLE 7. COMPOSITE SCORES OF PROGRAM GENEROSITY IN SICKNESS INSURANCE FOR DENMARK, NORWAY AND SWEDEN.

( High score = high attraction)

$\begin{array}{lllllll}\text { Denmark } 1965 & 14.65 & & \text { Norway } & 1965 & 16.43 \\ \text { Denmark } 1970 & 17.65 & & \text { Norway } & 1970 & 18.73 \\ \text { Denmark } 1975 & 21.95 & & \text { Norway } & 1975 & 21.07 \\ \text { Denmark } 1980 & 23.27 & & \text { Norway } & 1980 & 24.10 \\ \text { Denmark } 1985 & 21.55 & & \text { Norway } & 1985 & 24.10 \\ & & & & & \\ & & \text { Sweden } & 1965 & 24.33 & \\ & & \text { Sweden } & 1970 & 27.87 & \\ & & \text { Sweden } & 1975 & 28.57 & \\ & & \text { Sweden } & 1980 & 28.57 & \\ & \text { Sweden } & 1985 & 28.57 & \end{array}$

Source: Nordic Welfare State project Regime Databank. 
TABLE 8. GENEROSITY DIFFERENTIALS BETWEEN SICKNESS INSURANCE, UNEMPLOYMENT INSURANCE, AND EARLY RETIREMENT .

$\begin{array}{lccc} & \begin{array}{c}\text { Sickness/ } \\ \text { unemployment } \\ \text { ratio }\end{array} & \begin{array}{c}\text { Sickness/ } \\ \text { retirement } \\ \text { ratio }\end{array} \\ \text { Denmark } 1965 & 0.96 & 0.55 \\ \text { Denmark } 1970 & 0.65 & 0.71 \\ \text { Denmark } 1975 & 0.80 & 0.91 \\ \text { Denmark } 1980 & 1.00 & 1.02 \\ \text { Denmark } 1985 & 1.52 & 1.13 \\ & & & 1.03 \\ \text { Norway } 1965 & 1.35 & 1.22 \\ \text { Norway } & 1970 & 1.02 & 1.33 \\ \text { Norway } & 1975 & 1.25 & 1.37 \\ \text { Norway } & 1980 & 1.63 & 1.16 \\ \text { Norway } 1985 & 1.63 & 0.98 \\ & & & 1.23 \\ \text { Sweden } & 1965 & 1.25 & 1.11 \\ \text { Sweden } 1970 & 1.87 & 1.23 \\ \text { Sweden } 1975 & 1.24 & \end{array}$

Source: Nordic Welfare State project Regime Databank. 
TABLE 9. SICKNESS ABSENCE AS A PERCENT OF TOTAL PAID ABSENCE FROM WORK IN SWEDEN (1965-85) AND NORWAY (1972-85).

$\begin{array}{ll}\text { SWEDEN } & \text { NORWAY } \\ \text { (totals) (men) (women) (totals) }\end{array}$

$\begin{array}{ll}1965 & 38.2 \\ 1966 & 37.7 \\ 1967 & 38.5 \\ 1968 & 41.5 \\ 1969 & 41.1 \\ 1970 & 33.2 \\ 1971 & 33.9 \\ 1972 & 32.9 \\ 1973 & 30.1 \\ 1974 & 34.1 \\ 1975 & 37.7 \\ 1976 & 31.1 \\ 1977 & 29.7 \\ 1978 & 29.2 \\ 1979 & 27.8 \\ 1980 & 24.3 \\ 1981 & 23.8 \\ 1982 & 22.9 \\ 1983 & 24.6 \\ 1984 & 22.2 \\ 1985 & 27.3\end{array}$

Source: Nordic Weep Databank.

$\begin{array}{lll}48.2 & 40.1 & 45.2 \\ 48.8 & 44.9 & 47.2 \\ 49.2 & 42.0 & 46.5 \\ 44.3 & 40.0 & 42.5 \\ 51.2 & 39.7 & 45.8 \\ 52.9 & 40.1 & 47.3 \\ 49.9 & 38.9 & 44.7 \\ 48.7 & 35.7 & 42.6 \\ 51.1 & 34.5 & 42.9 \\ 47.1 & 38.3 & 42.5 \\ 46.2 & 37.1 & 41.5 \\ 48.2 & 36.8 & 42.4 \\ 49.6 & 37.6 & 43.1 \\ 46.8 & 38.5 & 42.3\end{array}$


Aarnio, M. Socialforsakringen och de Arbetsformogna i 1982 Norden. Stockholm: NU.

Blauner, R. Alienation and Freedom: - The Factory worker and 1967 his Industry. Chicago: University of Chicago Press.

Danzinger, S., Haveman, R. and Plotnik, R. "How Income 1981 Transfers Affect Work, Savings and Income Distribution". Journal of Economic Literature, 19.

Eriksen, T. Den Okada Sjukfranvaran. Stockholm: Prisma. 1980

Lindblom, C. Politics and Markets. New York: Basic Books. 1977

OECD, Measuring Health Care, 1960-1983. Paris: OECD. 1985

Polanyi, K. The Great Transformation. Boston: Beacon Press. 1957

Salowski, H.- Individuelle Fehlzeiten in Westlischen 1980 Industrie landern. Koln: DIV

Salowski, H.- Fehlzeiten. Koln: DIV 1983

Sundbo, J. et al.- Arbejdsfravaer. Copenhagen: SFI 1982

Taylor, D. "Absent Workers and Lost Hours". Monthly Labor 1979 Review, August. 
GRAPH 1

Sickness Absence

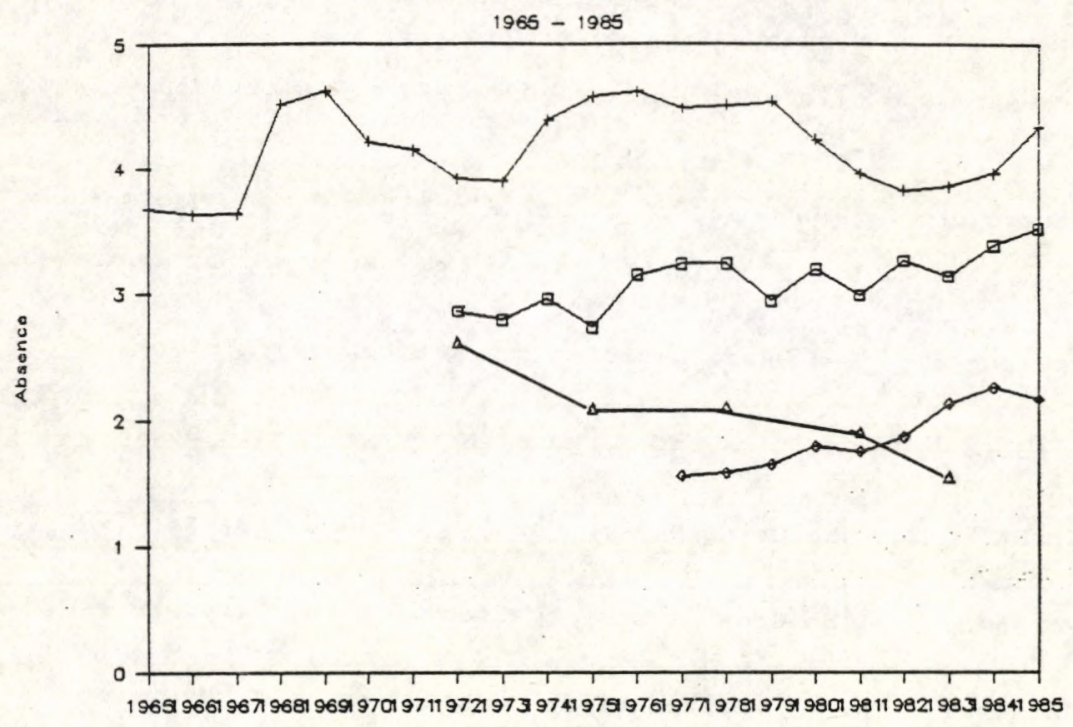

a Normay

+ Swoden

Year

Finland

$\Delta$ Denmark 
GRAPH 2 Sickness A'csence in Scandincvic

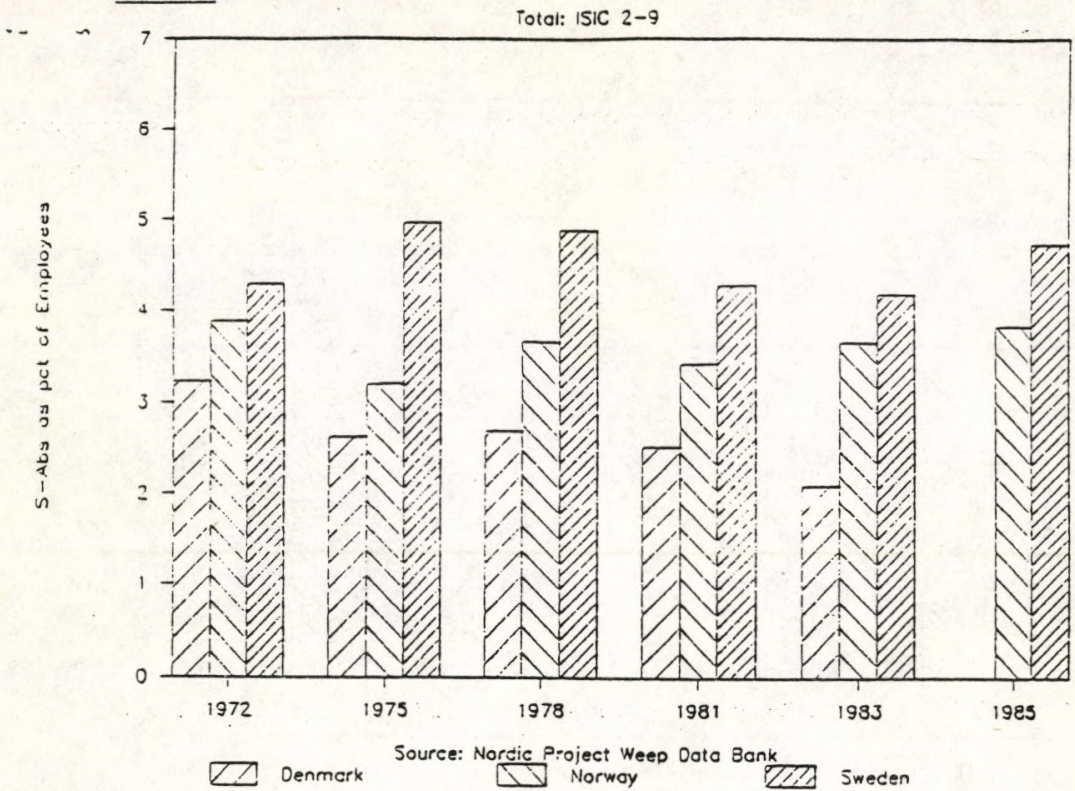

GRAPH 3 Sickness Absence in Scundinavia

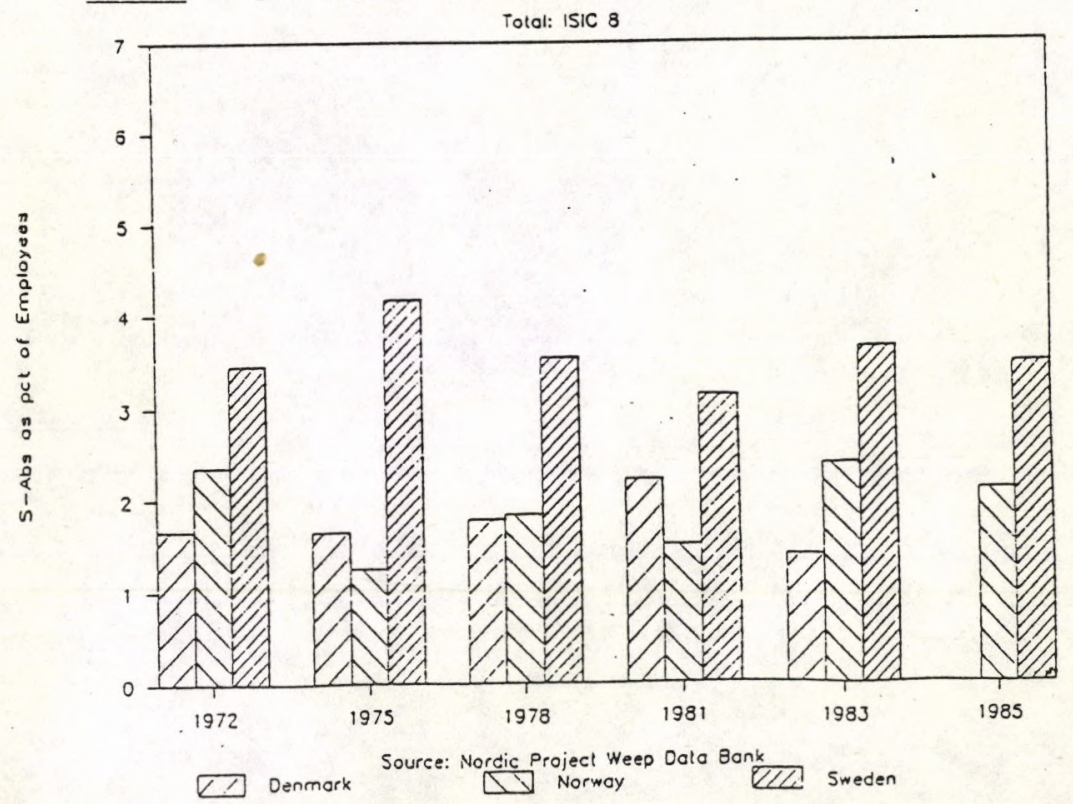

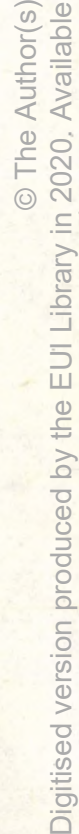


GRAPH 4 Sickness Mbsence in Scandinavic

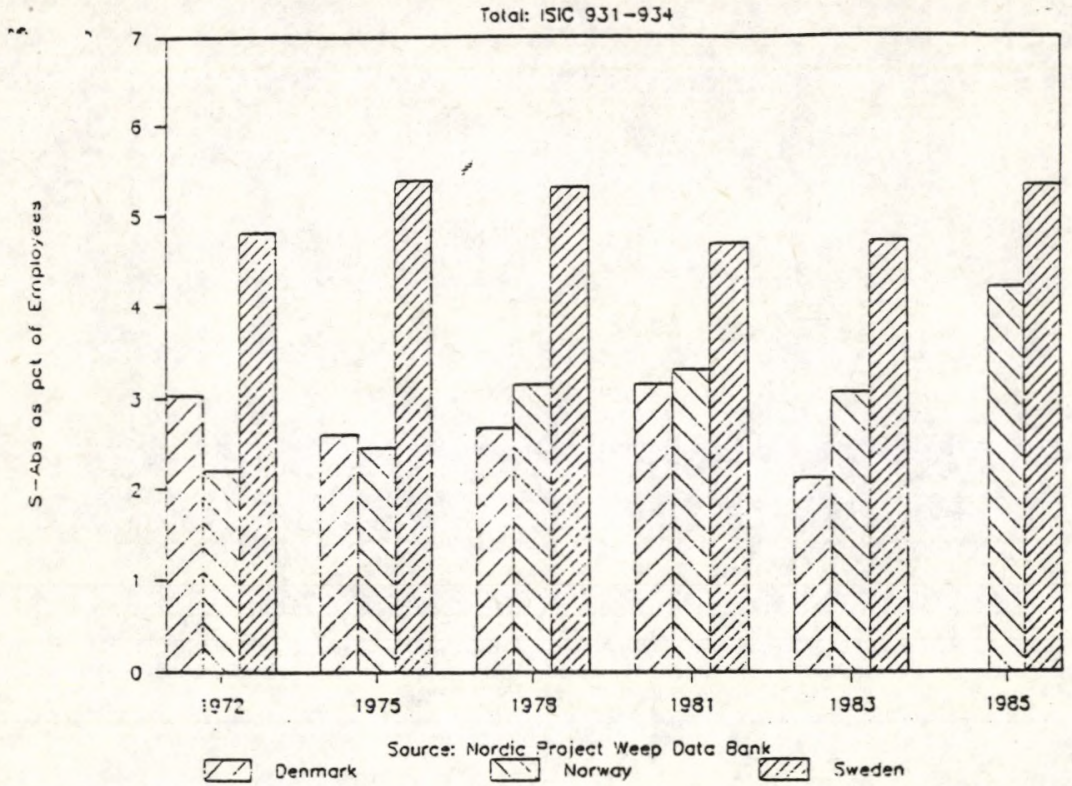




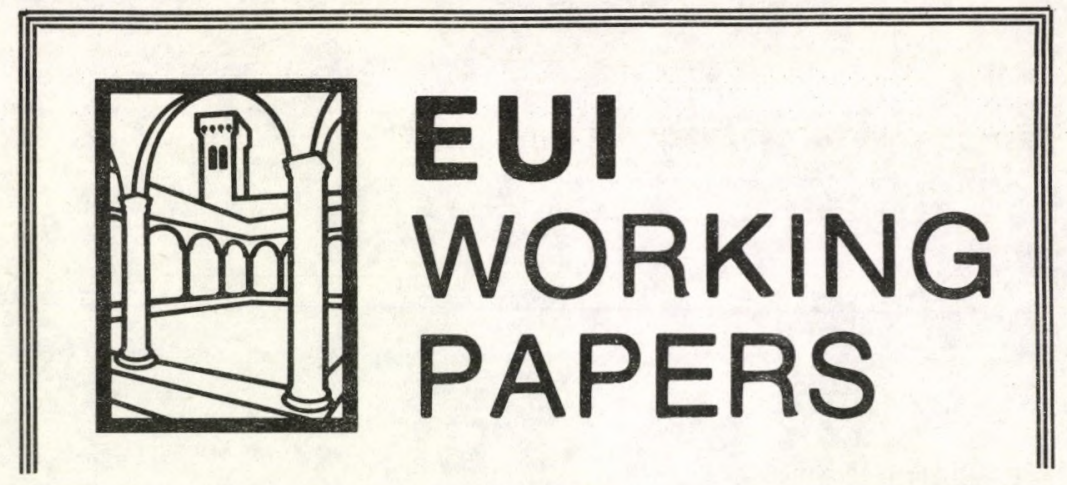

EUI Working Papers are published and distributed by the European University Institute, Florence.

A complete list and copies of Working Papers can be obtained free of charge - depending on the availability of stocks - from:

The Publications Officer

European University Institute

Badia Fiesolana

I - 50016 San Domenico di Fiesole (FI)

Italy

\section{Please use order form overleaf}


To

The Publications Officer

European University Institute

Badia Fiesolana

I - 50016 San Domenico di Fiesole (FI)

Italy

From Name

Address

Please send me:

a complete list of EUI Working Papers

the following EUI Working Paper(s):

No.:

Author, title:

Date:

Signature: 
87/315: Serge NOIRET

87/316: Alain GOUSSOT

87/317: Eamonn NOONAN

87/318: Jean-Pierre CAVAILLE

87/319: Peter RAPPOPORT and Lucrezia REICHLIN

87/320: Douglas GALE

87/321: Gianna GIANNELLI

87/322: Keith PILBEAM

87/323: Alan KIRMAN

87/324: Andreu MAS-COLELL

88/325: Angela GROPPI

88/326: Bernd MARIN

88/327: Jean BLONDEL

88/328: Ida KOPPEN
Nuovi motivi per studiare i meccanismi delle leggi elettorali. Una riflessione metodologica a proposito della legge del 1919 in Italia

Les sources internationales de la culture socialiste italienne à la fin du 19 e siècle et au début du 20 e siècle. Problèmes de la composition de l'idéologie du PSI et ses rapports avec la circulation des idées en Europe

Württemberg's exporters and German protection, 1931-36

Theatrum Mundi. Notes sur la théatralité du Monde Baroque.

Segmented Trends and Nonstationary Time Series

A Strategic Model of Labor Markets with Incomplete Information

A Monopoly Union Model of the Italian Labour Market

Sterilization and the Profitability of UK Intervention 1973-86

The Intrinsic Limits of Modern Economic Theory

An Equivalence Theorem for a Bargaining set

"La classe la plus nombreuse, la plus utile et la plus précieuse".

Organizzazione del lavoro e conflitti nella Parigi rivoluzionaria.

Qu'est-ce que c'est "Le Patronat"? Quelques enjeux théoriques et observations empiriques

Decision-Making Processes, Conflicts, and Cabinet Government *

The European Community's Environment Policy.

From the Summit in Paris, 1972, to the Single European Act, 1987 * 
88/329: Dalia MARIN

88/330: Milica UVALIC

88/331: David CANNING

88/332: Dalia MARIN

88/333: Keith PILBEAM

88/334: Hans Ulrich Jessurun d' OLIVEIRA

88/335: Felix Fitzroy and Kornelius Kraft

88/336: Norbert LORENZ

88/337: Domenico Mario NUTI

88/338: Pietro REICHLIN and Paolo SICONOLFI

88/339: Alfred STEINHERR

88/340: Frederick VAN DER PLOEG

88/341: David CANNING

88/342: Gunther TEUBNER

88/343: Jean BLONDEL
Assessing Structural Change: The Case of Austria *

"Shareholding" in Yugoslav Theory and Practice

Convergence to Equilibrium in a Sequence of Games with Learning

Trade and Scale Economies. A causality test for the U.S., Japan, Germany and the UK

Fixed versus Floating Exchange Rates Revisited

Die EWG und die Versalzung des Rheins

Piece Rates with Endogenous Monitoring Some Theory and Evidence

Die Übertragung von Hoheitsrechten auf die Europäischen Gemeinschaften

- verfassungsrechtliche Chancen und Grenzen einer europäischen Integration erläutert am Beispiel der Bundesrepublik Deutschland, Frankreichs und Italiens -

On Traditional Cooperatives and James Meade's Labour-Capital Discriminating Partnerships

Government Debt and Equity Capital in an Economy with Credit Rationing

The EMS with the ECU at Centerstage: A proposal for reform of the European Exchange rate system

Monetary and Fiscal Policy in Interdependent Economies with Capital Accumulation, Death and Population Growth

Optimal Monetary Policy in an Economy without a Forward Market for Labour

"And God Laughed..." Indeterminacy, Self-Reference and Paradox in Law

Ministerial Careers in Western European Governments 
88/344: Joerg MAYER

88/345: Keith PILBEAM

88/346: Ef isio ESPA

88/347: Francesc MORATA and and Jaume VERNET

88/348: Milica UVALIC

88/349: Massimo PANEBIANCO

88/350: Gregorio ROBLES

88/351: Alan KIRMAN

88/352: Gianna GIANNELLI

88/353: Niall O'HIGGINS

88/354: Christian JOERGES

88/355: Summary of Conference, debates and abstracts of selected interventions

88/356: Mary MCCARTHY and Lucrezia REICHLIN

88/357: Richard M. GOODWIN

88/358: Fernando PACHECO

Eric PEERE and

Francisco S. TORRES

88/359: Jaakko NOUSIAINEN
Intervention Mechanisms and Symmetry in the EMS

Exchange Rate Management and the Risk Premium

The Structure and Methodology of International Debt Statistics

Las Asambleas Regionales en Italia y España: Organizacion Institucional y Reglas de Funcionamiento

The Investment Behaviour of the Labour-Managed Firm: An Econometric Analys is

Inter-Regional Co-Operation in the North-South Dialogue

Latin America and the European Community

La Cour de Justice des CE et les Principes Généraux du droit

On Ants and Markets

Labour Demand, Pricing and Investment Decisions in Italy: An Econometric Analys is

The Progressivity of Government Taxes and Benefits in Ireland: A Comparison of Two Measures of Redistributive Impact

Amerikanische und deutsche Traditionen der soziologischen Jurisprudenz und der Rechtskritik

The Future Financing of the $\mathrm{EC}$ Budget: EPU Conference :-6-17 October 1987

Do Women Cause Unemployment?

Evidence From Eight O.E.C.D. Countries

Chaotic Economic Dynamics

Duopoly Under Demand Uncertainty

Substance and style of Cabinet Decision-Making 
PUBLICATIONS OF THE EUROPEAN UNIVERSITY INSTITUTE

DECEMBER 1988

88/360: Domenico Mario NUTI

88/361: Domenico Mario NUTI

88/362: Domenico Mario NUTI

88/363: Reiner GRUNDMANN

88/364: TONY PROSSER

88/365: Silke BRAMMER

88/366: Goesta ESPING-ANDERSEN

88/367: Goesta ESPING-ANDERSEN Paul FARSUND and Jon Eivind KOLBERG

88/368: Stephen MARTIN
Economic Relations between the European Community and CMEA

Remonetisation and Capital Markets in the Reform of Centrally Planned Economies

The New Soviet Cooperatives: Advances and Limitations

Marx and the Domination of Nature Alienation, Technology and Communism

The Privatisation of Public Enterprises in France and Great Britain The State, Constitutions and Public Policy

Die Kompetenzen der EG im Bereich Binnenmarkt nach der Einheitlichen Europäischen Akte

The Three Political Economies of the Welfare State

Decommodification and Work Absence in the Welfare State

Joint Ventures and Market Performance in oligopoly 
